\title{
Service Quality Measurement in Rural Tourism: Application of RURALQUAL Model
}

\author{
Suzana Marković \\ University of Rijeka, Faculty of Tourism and Hospitality Management, Croatia \\ suzanam@fthm.hr \\ Jelena Kljaić Šebrek \\ WYG Consulting Ltd, Croatia \\ jelenak1o1@gmail.com
}

The purpose of this paper is to evaluate service quality and its relation to customer satisfaction, trust, and behavioural intentions of rural tourism by applying the modified RURALQUAL model derived from the original SERVQUAL model. The survey was conducted on a sample of 307 rural tourists in Croatia. A Partial Least Squares Structural Equation Modelling (PLS-SEM) was applied in order to analyse the relationship between the measured constructs. The modified RURALQUAL model has been proven as a reliable and valid multidimensional scale that includes 27 items divided into 5 dimensions. Results indicate that there is a significant positive relationship between Service quality and Satisfaction as antecedents to Loyalty. The role of Trust as a mediator between Satisfaction and Loyalty has been proven, but its mediation power is rather small. Research results indicate that rural tourism managers and owners paid more attention to the tangible service quality elements, but in order to improve overall tourist experience in the future, they should pay more attention to the intangible service quality elements. The modified RURALQUAL instrument should be periodically used as a tool by practitioners and managers for the future development of rural tourism.

Keywords: service quality, satisfaction, loyalty, rural tourism, RURALQUAL, PLS

SEM

(cc)BY-SA https://doi.org/10.26493/2335-4194.13.215-227

\section{Introduction}

The importance of rural tourism, which has come under the focus of many researchers, has significantly increased in the last decades (Hurst et al., 2009; Osman \& Sentosa, 2013b). Rural tourism may be an answer to the redundant sun and sea concept and an extension of the main tourist season for many tourist economies (Grgić et al., 2017). Furthermore, the urban accelerated lifestyle has become very stressful, causing many tourists to seek calm, rural places surrounded by nature (Kastenholz et al., 2018). Rural tourism presents a powerful development strategy for rural underdeveloped areas as it generates new jobs and increases local incomes (Choi et al., 2018). The development potential of rural tourism is huge, but in order to stay competitive and sustainable in the long term, rural tourism must provide a high level of service quality and satisfaction (Chatzigeorgiou \& Simeli, 2017). According to Rozman et al. (2009), service quality is important for survival in a competitive market. Satisfied tourists are more likely to recommend and return to the rural tourist object. Service quality is a widely researched 
concept in the tourism industry, but only a few studies have measured service quality in rural tourism using Partial Least Squares Structural Equation Modelling (PLS-SEM), including Loureiro and Kastenholz (2011), Osman and Sentosa (2013a, 2013b, and Kastenholz et al. (2018).

Therefore, the purpose of this paper is to determine service quality in rural tourism. The main research objectives of this study are: (a) to assess Service quality, Satisfaction and Loyalty in rural tourism, (b) to evaluate the relationship between Service quality, Satisfaction and Loyalty, (c) to estimate the role of Trust as a mediator between the concepts Satisfaction and Loyalty, and (d) to test the reliability of the modified RU RALQUAL model.

The paper is organised in four sections. The following section provides an overview of the recent literature dealing with the concepts and measurement of service quality, tourist satisfaction and loyalty, primarily in rural tourism. The next section lays out the methodology and is followed by the results of the research. The final section discusses main conclusions, limitations, and future research proposals.

\section{Literature Review}

Although there is no unique definition of the term 'service quality,' most researchers agree that the term defines fulfilment of tourists' expectations in the focus of service quality (Gronroos, 1984; Parasuraman et al., 1985; Lewis \& Mitchell, 1990). According to many authors, service quality is a multidimensional concept, but service quality dimensions should be adapted to the specific features of a measured service (Babakus \& Boller, 1992).

So far, a wide range of research has been conducted on service quality and a variety of different measurement models has been developed and tested, but one of the most popular and frequently used is the SERVQUAL model. SERVQUAL was developed by Parasuraman et al. in 1985. It consists of 22 items which measure five service quality dimensions: Tangibles, Reliability, Responsiveness, Assurance, and Empathy. The SERVQUAL instrument was widely used for measuring service quality in the tourism industry: travel agencies (Bigne et al., 2003; Shahin \& Janatyan,
2011; Katircioglu et al., 2012; Setó-Pamies, 2012; Rajesh, 2018), hotels (Marković, 2004; Ladhari, 2009; Marković \& Raspor, 2010; Marković \& Raspor Janković, 2013; Kim-Soon et al., 2014; Ounsri \& Thawesaengskulthai, 2019), and restaurants (Marković et al., 2010; Nam \& Lee, 2011; Hansen, 2014; Saneva \& Chortoseva, 2018). SERVQUAL was also used to measure the quality of rural tourism. For that purpose, a RURALQUAL model was developed by Loureiro and Gonzalez (2008). The model assesses only perceptions as proposed by Cronin and Taylor (1994) and consists of 22 variables divided into 6 factors (Professionalism, Reservations, Tangibility, Complementary benefits, Rural and cultural environment and Basic benefits). Research on a sample of 198 rural tourists was conducted in 2008 in Portugal. The research proved that the lowest-rated service quality dimension is Rural and cultural environment, and the highest-rated dimensions are Professionalism, Reservations, Tangibility and Basic benefits.

Satisfaction is also a very frequently-researched concept in tourism due to its importance for the success of tourism business, as a satisfied tourist is more likely to recommend or rebuy the service (Baker \& Crompton, 2000; Su \& Fan, 2011). Satisfaction is, by most authors, defined as an emotion that a tourist feels after service consumption or an affective response to a service (Oliver, 1999; Baker \& Crompton, 2000; Zeithaml \& Bitner, 2003; Um et al., 2006). Tourist satisfaction depends on the level of fulfilment of expectations and desires (Chen \& Tsai, 2007; Osman \& Sentosa, 2013a). If a perceived service did not meet expectations, a tourist may feel dissatisfied.

Loyalty presents the ultimate objective for many companies as it reduces costs and increases profit (Almeida-Santana \& Moreno Gil, 2018). Most authors emphasise that loyalty is a positive attitude towards a destination, a company, or a service (Oliver, 1999; Kim \& Brown, 2012; Setó-Pamies, 2012; Osman \& Sentosa, $2013 \mathrm{~b}$ ). The concept of loyalty can be approached from two different directions: attitudinal or behavioural (Zeithaml, 200o). Behavioural loyalty results in repetitive purchasing behaviour while attitudinal includes recommending a service or company to others (Zeithaml, 2000; Cheng, 2011). 
The concept of Trust has been defined as a tourist's 'willingness to rely on tourist attraction operator's ability to deliver what has been promised and meet or exceed the expectation of the tourists which has been built around of the knowledge about the tourist attraction' (Osman \& Sentosa, 2013a, p. 14.). Many studies emphasize that Trust reduces risk and effects future intentions, especially in long-term, strong relationships with the company (Sirdeshmukh et al., 2002; Yieh et al., 2007; Loureiro \& Gonzalez, 2008).

Studies carried out by different authors have proven that Service quality, Satisfaction and Loyalty are related concepts. High quality of service effects tourists' positive emotions and generates high tourist satisfaction. Satisfaction, enhanced by Trust, contributes to Loyalty. Service quality and Tourist satisfaction have been proven to be the key antecedents to customer Loyalty by different studies (Loureiro \& Kastenholz, 2011; Oh \& Kim, 2017). The mediating effect of Trust on Loyalty in rural tourism has been proven by Loureiro and Gonzalez (2008).

The review of selected recent researches on service quality and related concepts in rural tourism is given in Table 1. The data show that Service quality, Satisfaction and Loyalty in rural tourism are measured globally in different tourist countries (Us A, Spain, Greece, Slovenia, Portugal, Malaysia). The authors used quite large samples, ranging from 103 to 632 respondents. Most of the researches followed the SERVQUAL model modified to the needs of the services measured, where the number of factors varied from the original 5 to 8 factors and 22 to 36 variables. The applied statistical methods primarily include factor analysis and structural modelling. The observed studies reported a high level of reliability $(>0.70)$ of applied models. The findings of the research conducted by Choi et al. (2018) indicate that performance exceeds expectations, meaning that rural tourists' needs are met for all the observed variables. On the other hand, Albacete-Saez et. al. (2007) proved a negative gap between perception and expectation in 4 of 5 service quality dimensions. A positive gap is proved for the dimension Empathy, and the largest negative gap is recorded for the dimension Complementary offer.

Furthermore, the previously analysed studies con-

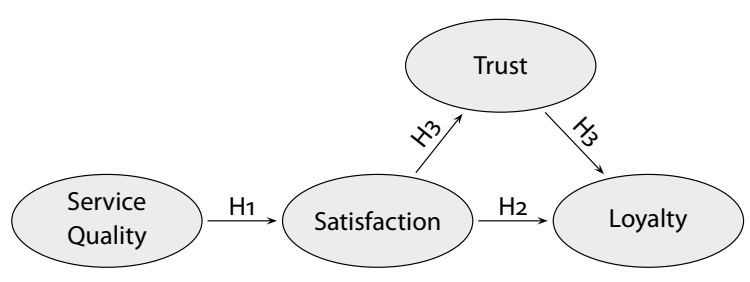

Figure 1 Theoretical Framework

firmed that the concepts Service quality, Satisfaction and Loyalty are related and interdependent. More specifically, Loureiro and Kastenholz (2011) and Su and Fan (2011) found that high service quality significantly increases tourist satisfaction and confirmed that satisfaction is the key antecedent to loyalty. Also, the study of Su and Fan (2011) has proven that there is no direct relationship between service quality and loyalty, but only mediated by tourist satisfaction and trust. Also, this study confirmed that satisfaction is an antecedent to trust, not the opposite. A study of Peãa et al. (2012), conducted in Spain, emphasises the positive effect of the perceived value on tourist satisfaction. Osman and Sentosa (2013b) conducted research on service quality in rural tourism in Malaysia that proved a strong direct relationship between service quality and satisfaction and service quality and loyalty. The same study confirmed that satisfaction and trust could have a mediating role between service quality and loyalty.

The findings of the study carried out in Greece by Chatzigeorgiou and Simeli (2017) confirmed the predicative power of overall service quality and satisfaction on loyalty. Rajaratnam et al. (2015), in their study on 334 rural tourists in Malaysia, have found that satisfaction is positively and significantly correlated to loyalty.

Although there is no consensus on service quality attributes, most of the authors agree that initial SERVQUAL dimensions should be adapted to specific needs of a wide range of rural tourism activities.

Based on the literature review the following hypotheses were tested (Figure 1):

$\mathrm{H} 1$ There is a positive relationship between service quality and customer satisfaction.

$\mathrm{H} 2$ There is a positive relationship between customer satisfaction and customer loyalty. 
Table 1 Literature Review of Measuring Service Quality, Satisfaction and Loyalty in Rural Tourism

\begin{tabular}{|c|c|c|c|c|c|c|}
\hline (1) & $(2)$ & (3) & (4) & (5) & $(6)$ & $(7)$ \\
\hline $\begin{array}{l}\text { Albacete-Saez et al. } \\
(2007)\end{array}$ & Spain & 185 & Service quality & $\begin{array}{l}7 \text { factors, } \\
36 \text { items }\end{array}$ & $\mathrm{EFA}^{*}$ & 0.93 \\
\hline Hurst et al. (2009) & USA & 125 & $\begin{array}{l}\text { Service quality, satisfaction, } \\
\text { loyalty }\end{array}$ & $\begin{array}{l}5 \text { factors, } \\
18 \text { items }\end{array}$ & EFA & $0.82-0.98$ \\
\hline Rozman et al. (2009) & Slovenia & 103 & Service quality & $\begin{array}{l}3 \text { service quality } \\
\text { dim., } 22 \text { items }\end{array}$ & DEX & - \\
\hline $\begin{array}{l}\text { Fotiadis \& Vassiliadis } \\
(2010)\end{array}$ & Greece & 219 & Satisfaction & 15 items & IPA & - \\
\hline $\begin{array}{l}\text { Loureiro \& Kastenholz } \\
(2011)\end{array}$ & Portugal & 161 & $\begin{array}{l}\text { Service quality, corporate repu- } \\
\text { tation, satisfaction, loyalty }\end{array}$ & $\begin{array}{l}6 \text { factors, } \\
22 \text { items }\end{array}$ & $\begin{array}{l}\text { CFA, } \\
\text { PLS-SEM }\end{array}$ & 0.92 \\
\hline Su \& Fan (2011) & China & 320 & $\begin{array}{l}\text { Service quality, satisfaction, } \\
\text { trust, loyalty }\end{array}$ & 5 factors & SEM & $0.77-0.85$ \\
\hline Peña et al. (2012) & Spain & 632 & $\begin{array}{l}\text { Perceived value, satisfaction, } \\
\text { loyalty }\end{array}$ & - & SEM & $>0.70$ \\
\hline $\begin{array}{l}\text { Osman \& Sentosa } \\
(2013 a)\end{array}$ & Malaysia & 295 & $\begin{array}{l}\text { Service quality, satisfaction, } \\
\text { loyalty }\end{array}$ & $\begin{array}{l}5 \text { factors, } 31 \\
\text { items in total }\end{array}$ & PLS-SEM & $0.84-0.91$ \\
\hline $\begin{array}{l}\text { Rajaratnam et al. } \\
(2015)\end{array}$ & Malaysia & 334 & $\begin{array}{l}\text { Destination quality, satisfac- } \\
\text { tion, loyalty }\end{array}$ & 8 factors & PLS-SEM & $0.90-0.92$ \\
\hline Rozkee et al. (2016) & India & 420 & Service quality, satisfaction & $\begin{array}{l}5 \text { factors, } \\
22 \text { items }\end{array}$ & regression & - \\
\hline $\begin{array}{l}\text { Chatzigeorgiou \& } \\
\text { Simeli (2017) }\end{array}$ & Greece & 400 & $\begin{array}{l}\text { Service quality, satisfaction, } \\
\text { future behavioural intentions }\end{array}$ & $\begin{array}{l}5 \text { factors, } \\
22 \text { items }\end{array}$ & SEM & - \\
\hline Kastenholz et al. (2018) & Portugal & 252 & $\begin{array}{l}\text { Tourists' arousal, memory, } \\
\text { satisfaction }\end{array}$ & - & PLS-SEM & - \\
\hline Choi et al. (2018) & $\begin{array}{l}\text { South } \\
\text { Korea }\end{array}$ & 442 & Service quality & 18 items & $\mathrm{IPA}^{* *}$ & 0.96 \\
\hline
\end{tabular}

Notes Column headings are as follows: (1) author, (2) country, (3) sample size, (4) measured concepts, (5) number of service quality items and factors, (6) methods used, (7) reliability. ${ }^{\star}$ Exploratory Factor Analysis, ${ }^{\star *}$ Importance Performance Analysis.

$\mathrm{H} 3$ There is a positive mediating effect of trust on the satisfaction and loyalty relationship.

A literature review indicates that PLS SEM is an often-used method in research in service quality in tourism. According to the results of a study conducted by Ali et al. (2017), during the period between 2001 and 2015 there were 29 empirical articles published that applied PLS-SEM. Out of 29 articles, only 7 were published up until 2012, and 22 articles were published from 2013 to 2015, indicating an increasing popularity of PLS SEM in recent years.

\section{Methodology}

The perceived quality of the rural tourism was measured using a modified RURALQUAL model based on the SERVQUAL and the original RURALQUAL model (Loureiro \& González, 2008) and modified by the items used in the study of Albacete-Saez et al. (2007). Modifications include adaptation of the items to the specific features of rural tourism in Istria. The dimension Safety was added from the model of AlbaceteSaez et al. (2007). Safety was identified as a very important service quality aspect during the consultation process with key tourist stakeholders in Istria (tour- 
ist board and rural tourism managers and owners).

The scale contains 27 items divided into 5 factors measured on a 7-point Likert-type ordinal scale. The research conducted in this work used measurement of perception only as proposed by Cronin and Taylor (1994).

The survey was conducted from June to September 2017 in central Istria as one of the most developed rural tourism destinations in Croatia. There were 1,400 paper questionnaires in 4 languages distributed to tourists staying in 22 rural accommodations. 307 valid questionnaires were returned (return rate $21.93 \%$ ) using a convenient sample, meaning that only tourists who were available and willing to participate in research filled in the questionnaires. Descriptive statistics, factor analysis and Partial Least Squares Structural Equation Modelling (PLS-SEM) methods were performed using SPSS 20.0 and Smart PLS 2.0 software to test the research hypotheses.

PLS SEM became the preferred technique due to its advantages: accuracy for small sample size, absence of distributional assumptions and a high degree of statistical power (Hair et al., 2019). It is an appropriate technique in the case of complex structural models that include many constructs, indicators, and model relationships (Hair et al., 2019).

PLS SEM is based on an iterative combination of principal components analysis and regression, aiming at explaining the variance of the constructs in the model (Chin, 1998; Peng, 2012). The advantage of PLS SEM lies in simultaneously estimating all relationships in the model including path coefficients and individual item loadings of the model, eliminating concerns about multicollinearity (Henseler et al., 2009).

The model consists of two parts (Hair et al., 2013): the structural model analysing the relationships between the constructs (inner model) and the measurement models displaying the relationships between the constructs and the indicator variables (outer model). The application of PLS SEM is a multi-stage approach that involves three main stages: model specification, outer model evaluation and inner model evaluation (Hair et al., 2014). The inner model evaluation as a last stage is implemented only after the previous stage proves the reliability and validity of the model
(Henseler et al., 2009). PLS-SEM relies on a nonparametric bootstrap procedure to test coefficients for their significance. In bootstrapping, a large number of subsamples are drawn from the original sample and used to evaluate the model (Hair et al., 2013).

This paper presents an evaluation of the structural model including the relationship between constructs of service quality, satisfaction, trust and loyalty.

Since PLS SEM is considered more appropriate for prediction than covariance-based techniques (Loureiro \& Kastenholz, 2011), it has been chosen for the analysis of future behaviour intentions. Adequacy of measurement was assessed by evaluating the reliability and the discriminant validity of the scale. The Partial Least Squares (PLS) approach was employed to estimate the structural paths coefficients, $R^{2}$ for evaluation of predictive power of the model and $Q^{2}$ for assessment of predictive relevance, and the Bootstrap technique to test the hypotheses.

\section{Research Results}

The data analysis of socio-demographic data indicates that there was an almost equal number of female and male respondents. Out of 307 respondents, $68.32 \%$ are foreign tourists. The majority of respondents are between 30 and 49 years old $(58.17 \%)$ with a middle or high school level of education (84.97\%) and dominant marital status 'married' (48.36\%). Most of the respondents were visiting the rural destination facility for the first time (72.04\%) and travelling with a partner or friends $(55.88 \%)$. The main tourist motives for visiting the rural facility are spending time with friends and family (51.14\%) and relaxing (40.39\%). Other motives include tasting local food, learning about tradition and culture, and escaping from stress and city noise. The results of the socio-demographic profile of respondents is shown in Table 2.

The results of the principal components analysis and Promax rotation method were used to reduce 27 variables to 5 factors (Safety, tourist relations and rural surrounding, Tangibility and basic demand, Price and reservation, Professionalism, and Empathy). The communality values of the observed variables are above 0.5 , indicating suitability of the items for performing factor analysis. 
Table 2 Respondents Socio-Demographic Profile

\begin{tabular}{|c|c|c|c|}
\hline Item & Group & $f$ & $\%$ \\
\hline \multirow[t]{3}{*}{ Gender } & Female & 158 & 51.63 \\
\hline & Male & 148 & 48.37 \\
\hline & Total & 306 & 100.00 \\
\hline \multirow[t]{7}{*}{ Age } & Less than 20 & 15 & 4.90 \\
\hline & $20-29$ & 59 & 19.28 \\
\hline & $30-39$ & 96 & 31.37 \\
\hline & $40-49$ & 82 & 26.80 \\
\hline & $50-59$ & 26 & 8.50 \\
\hline & 60 and above & 28 & 9.15 \\
\hline & Total & 306 & 100.00 \\
\hline \multirow{5}{*}{$\begin{array}{l}\text { Educational } \\
\text { level }\end{array}$} & Elementary school or less & 11 & 3.59 \\
\hline & Secondary school & 126 & 41.18 \\
\hline & University & 134 & 43.79 \\
\hline & Master or $\mathrm{PhD}$ & 35 & 11.44 \\
\hline & Total & 306 & 100.00 \\
\hline \multirow{5}{*}{$\begin{array}{l}\text { Marital } \\
\text { status }\end{array}$} & Single & 80 & 26.32 \\
\hline & Married & 147 & 48.36 \\
\hline & In relationship & 67 & 22.04 \\
\hline & Other & 10 & 3.29 \\
\hline & Total & 304 & 100.00 \\
\hline \multirow{7}{*}{$\begin{array}{l}\text { Travelling } \\
\text { group }\end{array}$} & Alone & 35 & 11.44 \\
\hline & Partner & 102 & $33 \cdot 33$ \\
\hline & Partner and children & 60 & 19.61 \\
\hline & Friends & 69 & 22.55 \\
\hline & Work colleagues & 34 & 11.11 \\
\hline & Other & 6 & 1.96 \\
\hline & Total & 306 & 100.00 \\
\hline
\end{tabular}

Continued in the next column

Total variance explained in factor analysis is $65.17 \%$; the majority of total variance is explained by the first factor $42.98 \%$ followed by the second factor $9.79 \%$, third factor $5.09 \%$, fourth factor $3.85 \%$ and fifth factor $3.56 \%$.

The first factor, Safety, tourist relations and rural surrounding, refers to the usage of safety measures, integration of tourists into the local lifestyle, and offer of additional activities and events in the rural surround-
Table 2 Continued from the previous column

\begin{tabular}{|c|c|c|c|}
\hline Item & Group & $f$ & $\%$ \\
\hline \multirow[t]{20}{*}{ Country } & Croatia & 100 & 32.68 \\
\hline & Germany & 47 & $15 \cdot 36$ \\
\hline & Austria & 46 & 15.03 \\
\hline & $\mathrm{UK}$ & 30 & 9.80 \\
\hline & Italy & 29 & 9.48 \\
\hline & Slovenia & 15 & 4.90 \\
\hline & Netherlands & 7 & 2.29 \\
\hline & Ireland & 6 & 1.96 \\
\hline & Switzerland & 5 & 1.63 \\
\hline & USA & 4 & 1.31 \\
\hline & Hungary & 3 & 0.98 \\
\hline & Canada & 3 & 0.98 \\
\hline & Slovakia & 3 & 0.98 \\
\hline & Denmark & 2 & 0.65 \\
\hline & San Marino & 2 & 0.65 \\
\hline & Australia & 1 & 0.33 \\
\hline & Russia & 1 & 0.33 \\
\hline & Spain & 1 & 0.33 \\
\hline & Luxemburg & 1 & 0.33 \\
\hline & Total & 306 & 100.0 \\
\hline \multirow{4}{*}{$\begin{array}{l}\text { Number of } \\
\text { arrivals }\end{array}$} & First time & 219 & 72.04 \\
\hline & 2 to 5 times & 56 & 18.42 \\
\hline & More than 5 times & 29 & 9.54 \\
\hline & Total & 304 & 100.00 \\
\hline
\end{tabular}

ing. The second factor, Tangibility and basic demand, includes attributes like rural facility location, state of rural facilities, and external and internal decoration. The third factor, Price and reservations, describes reservation possibilities and accordance of price and services. The fourth factor, Professionalism, refers to employees' appearance and treatment of tourists. The last factor, named Empathy, includes items regarding employees' knowledge of foreign languages and individual approach to the tourists. The number of items varies from 3 to 10 per factor. Factor mean scores range from 5.46 to 6.05 with the highest mean score for the factor Tangibility and basic demand and the lowest 
Table 2 Continued from the previous column

\begin{tabular}{llrr}
\hline Item & Group & $f$ & $\%$ \\
\hline Travel & Spending time with friends & 157 & 51.14 \\
motives & and family & & \\
& Relaxing & 124 & 40.39 \\
& Tasting local food & 85 & 27.69 \\
& Learning about local tradi- & 55 & 17.92 \\
& tion/culture & & \\
& Escape from stress and city & 77 & 25.08 \\
& noise & & \\
& Beautiful nature & 70 & 22.80 \\
& Searching for tranquillity & 39 & 12.70 \\
& Beauty of a place & 30 & 9.77 \\
& Affordable prices & 28 & 9.12 \\
& Pleasant atmosphere & 23 & 7.49 \\
& Learning new skills & 30 & 9.77 \\
& Other & 14 & 4.56 \\
\hline
\end{tabular}

mean score for the factor Safety, tourist relations and rural surrounding. An overall average mean score for Perceived service quality is 5.79 . The highest mean score was given to the item The lodging is located in a calm place (6.28, St. dev 0.89), and the lowest to the item The Rural establishment observes safety measures during excursions and complementary activities offered (5.20, St. dev. 1.53). The overall average service quality score is relatively high (5.79). The highest score was given to the dimension Tangibility and basic demand (6.05) that refers to infrastructure, equipment and decoration. The lowest score was given to the dimension Safety, tourist relations and rural surrounding (5.46).

All factor loadings for service quality items are significant with the value above 0.5 and the overall Cronbach alpha 0.952 indicating good reliability of the scale. The statistical calculations were performed using SPSS 20.0. The factor structure of modified RURALQUAL model is shown in Table 3.

An overall mean score for Satisfaction is 5.82, Trust 5.98 and Loyalty 5.15. All factor loadings are significant since they are greater than 0.5. The Cronbach alpha coefficient ranges from 0.865 to 0.910 , proving a good internal consistency of the constructs. The results of quantitative analysis for the concepts Satisfaction, Trust and Loyalty are shown in Table 4.

The Cronbach alpha value for all measured constructs is between 0.762 and 0.951 and indicates a good reliability or internal consistency of the modified RU RALQUAL model (Table 5). Convergent validity has also been confirmed as factor loadings prove a strong connection of items to the factors, given that the average variance extracted by the constructs (AVE) was at least 0.5. The results of $R^{2}$ prove moderate predictive power of the model since the values exceed 0.50 . The literature suggests that $R^{2}$ values of $0.67,0.33$, and 0.19 are substantial, moderate, and weak (Chin, 1998; Peng, 2012). The values for $Q^{2}$ are all positive, meaning that the model has predictive relevance.

PLS SEM was used to assess path coefficients between the observed constructs. The results prove a strong direct positive relationship between Service Quality and Satisfaction (0.763) and Between Satisfaction and Loyalty (0.652). Also, Satisfaction has been proven to be strongly related to Trust, but the relationship between Trust and Loyalty is rather weak (0.146). The path coefficient analysis of the service quality dimensions indicates that the most important dimension in forming service quality is Safety, tourist relations and rural surrounding (43\%), while the dimension Empathy has the lowest impact on forming the Service Quality construct (13\%). The results of Path coefficient analysis are shown in Figure 2.

The Bootstrap technique in PLS SEM was applied for the assessment of the significance level of the path coefficients in order to test the hypothesis. According to the results all the relations between the constructs have been proven to be significant at the 0.001 level, except for the relation between Trust and Loyalty that is positive, but weak and significant at the 0.005 level (Table 6). The path coefficient between Satisfaction and Loyalty decreased when the mediator Trust was introduced, proving the existence of the mediation role of Trust.

The strength of the mediating role of Trust was evaluated by calculating VAF (Variance accounted for), as suggested by Hair et al. (2013). A vaf value below $20 \%$ means that the role of the mediator is small. Since 
Table 3 Factor Structure of Modified RURALQUAL Model

\begin{tabular}{|c|c|c|c|}
\hline Factor & Item & (1) & (2) \\
\hline \multirow{10}{*}{$\begin{array}{l}\text { Safety, tourist } \\
\text { relations and } \\
\text { rural } \\
\text { surrounding }\end{array}$} & The rural establishment is fitted with all necessary safety measures. & $5.32(1.58)$ & 0.792 \\
\hline & $\begin{array}{l}\text { The RE observes safety measures during excursions and complementary activities } \\
\text { offered. }\end{array}$ & $5.20(1.53)$ & 0.820 \\
\hline & Staff give us good advice regarding the gastronomy of the place. & $5.50(1.33)$ & 0.811 \\
\hline & All areas are well indicated with signs. & $5.23(1.56)$ & 0.872 \\
\hline & The communication (access) routes are well indicated with signs. & $5.45(1.30)$ & 0.865 \\
\hline & The clients are integrated in the region's rural lifestyle. & $5.30(1.48)$ & 0.873 \\
\hline & Staff give us good advice regarding complementary activities that are available. & $5.65(1.21)$ & 0.800 \\
\hline & Typical gastronomy of the region is included on the menu. & $5.64(1.29)$ & 0.781 \\
\hline & $\begin{array}{l}\text { In the surrounding region there are fairs, local festivities, and other aspects of } \\
\text { cultural interest. }\end{array}$ & $5.62(1.29)$ & 0.626 \\
\hline & Staff at our disposal know the traditions, celebrations and history of the place. & $5.64(1.21)$ & 0.734 \\
\hline \multirow{6}{*}{$\begin{array}{l}\text { Tangibility } \\
\text { and basic } \\
\text { demand }\end{array}$} & The lodging is placed in a calm place. & $6.28(0.89)$ & 0.709 \\
\hline & $\begin{array}{l}\text { Internal decoration (furniture, ceilings, lighting, floors, etc.) is pleasant, simple, } \\
\text { homey and in harmony with the rural surroundings. }\end{array}$ & $6.08(1.02)$ & 0.796 \\
\hline & $\begin{array}{l}\text { External decoration (facade, gardens, etc.) is attractive and in harmony with the } \\
\text { rural surroundings. }\end{array}$ & $6.11(1.00)$ & 0.749 \\
\hline & The rural lodging facilities are in a good state. & $5.96(1.95)$ & 0.667 \\
\hline & The lodging architecture has the regional style. & $5.91(1.07)$ & 0.733 \\
\hline & The lodging is placed in the area of great natural beauty. & $5.95(1.04)$ & 0.711 \\
\hline \multirow{4}{*}{$\begin{array}{l}\text { Price and } \\
\text { reservations }\end{array}$} & Room reservation is easy to do. & $5.82(1.19)$ & 0.832 \\
\hline & $\begin{array}{l}\text { The reservations are confirmed in the most convenient way for client, other } \\
\text { information of interest is sent back too (e.g. access map). }\end{array}$ & $5.72(1.20)$ & 0.844 \\
\hline & Arrival schedules are established but they are quite flexible. & $5.76(1.19)$ & 0.870 \\
\hline & Price is in accordance with the service provided. & $5.86(1.21)$ & 0.775 \\
\hline \multirow[t]{4}{*}{ Professionalism } & The clients are treated cordially and affably. & $6.07(1.00)$ & 0.748 \\
\hline & The rural lodging foods are well presented and flavoursome. & $5.93(1.03)$ & 0.768 \\
\hline & Personalized attention is provided to each client. & $5.84(1.16)$ & 0.738 \\
\hline & The rural lodging employees have a clean, neat appearance. & $6.07(0.95)$ & 0.798 \\
\hline \multirow[t]{3}{*}{ Empathy } & The rural establishment has staff that speak other languages. & $5.99(1.14)$ & 0.812 \\
\hline & Staff go out of their way to make sure customers understand them. & $6.02(1.06)$ & 0.861 \\
\hline & The rural establishment attends to customers individually (not as a group). & $5.87(1.17)$ & 0.830 \\
\hline
\end{tabular}

Notes Column headings are as follows: (1) mean (standard deviation), (2) factor loading.

the calculated VAF value was $\mathbf{1 4 . 2 1} \%$ it can be concluded that the mediator part of the relation between satisfaction and loyalty is very small.

Based on the given results, the Hypothesis $\mathrm{H} 1$ There is a positive relationship between service quality and customer satisfaction, $\mathrm{H} 2$ There is a positive relationship between customer satisfaction and customer loyalty, and $\mathrm{H} 3$ There is a positive mediating effect of trust on the satisfaction and loyalty relationship are supported. 
Table 4 The Results of Quantitative Analysis of the Constructs Satisfaction, Trust and Loyalty

\begin{tabular}{|c|c|c|c|}
\hline Construct & Item & $(1)$ & (2) \\
\hline \multirow[t]{8}{*}{ Satisfaction } & The stay here has been very satisfactory. & $5.83(0.923)$ & 0.727 \\
\hline & The rural lodging satisfies my necessities. & $5.94(1.020)$ & 0.825 \\
\hline & The rural lodging facilities are worthy of highlighting. & $5.69(1.087)$ & 0.807 \\
\hline & I find the lodging personnel pleasant. & $6.13(0.980)$ & 0.723 \\
\hline & $\begin{array}{l}\text { I am happy with cultural, sport and recreational activities provided by the lodging } \\
\text { and surrounding region. }\end{array}$ & $5.51(1.130)$ & 0.736 \\
\hline & The rural lodging delivers the service that I expected to receive. & $5.72(1.208)$ & 0.838 \\
\hline & The rural lodging delivers an excellent service. & $5.52(1.263)$ & 0.825 \\
\hline & In general, my experience here is positive. & $6.19(1.021)$ & 0.789 \\
\hline \multirow[t]{3}{*}{ Trust } & Here the promise is fulfilled. & $6.04(0.960)$ & 0.901 \\
\hline & I trust the service delivered by the rural lodging. & $6.16(0.909)$ & 0.921 \\
\hline & Here exists a real concern for my well-being. & $5.75(1.454)$ & 0.840 \\
\hline \multirow[t]{6}{*}{ Loyalty } & I will speak well about this lodging service to other people. & $5.66(1.009)$ & 0.747 \\
\hline & I will recommend the lodging if someone asks for my advice. & $5.61(1.061)$ & 0.789 \\
\hline & I will encourage my friends and relatives to visit this rural lodging. & $5.06(1.146)$ & 0.725 \\
\hline & In my next vacation I intend to return to this lodging. & $5.06(1.649)$ & 0.854 \\
\hline & I would come continually even if the lodging price increases. & $4.84(1.618)$ & 0.838 \\
\hline & $\begin{array}{l}\text { I prefer to pay a bigger price here than in other rural lodgings for the advantages } \\
\text { that I receive in this rural lodging. }\end{array}$ & $4.66(1.474)$ & 0.803 \\
\hline
\end{tabular}

Notes Column headings are as follows: (1) mean (standard deviation), (2) factor loading.

Table 5 Reliability, Validity and Prediction Attributes of the Modified RURALQUAL Model

\begin{tabular}{|c|c|c|c|c|c|c|}
\hline Construct & $(1)$ & (2) & (3) & (4) & (5) & (6) \\
\hline Service quality & 0.951 & 0.955 & - & 0.997 & 0.421 & 5.801 \\
\hline 1. Professionalism & 0.762 & 0.848 & 0.583 & - & & 5.980 \\
\hline 2. Price and reservations & 0.850 & 0.899 & 0.690 & - & & 5.788 \\
\hline 3. Tangibility and basic demand & 0.823 & 0.871 & 0.532 & - & & 6.056 \\
\hline 4. Empathy & 0.782 & 0.873 & 0.697 & - & & 5.964 \\
\hline 5. Safety, tourist relations and rural surrounding & 0.937 & 0.947 & 0.641 & - & & 5.462 \\
\hline Satisfaction & 0.910 & 0.928 & 0.616 & 0.583 & 0.352 & 5.830 \\
\hline Trust & 0.865 & 0.918 & 0.789 & 0.548 & 0.432 & 6.022 \\
\hline Loyalty & 0.882 & 0.911 & 0.630 & 0.587 & 0.351 & 5.201 \\
\hline
\end{tabular}

Notes Column headings are as follows: (1) reliability Cronbach Alpha, (2) composite reliability, (3) average variance extracted, (4) $R^{2}$ (predictive power of the model), (5) $Q^{2}$ (predictive relevance of the model), (6) latent variable index.

\section{Conclusions, Limitations, and Further Research} Rural tourism has been proven to be a very successful development strategy for rural areas. Competitive rural tourism requires continuous improvement of service quality and integration of different local resources and activities. However, in some cases, this is 


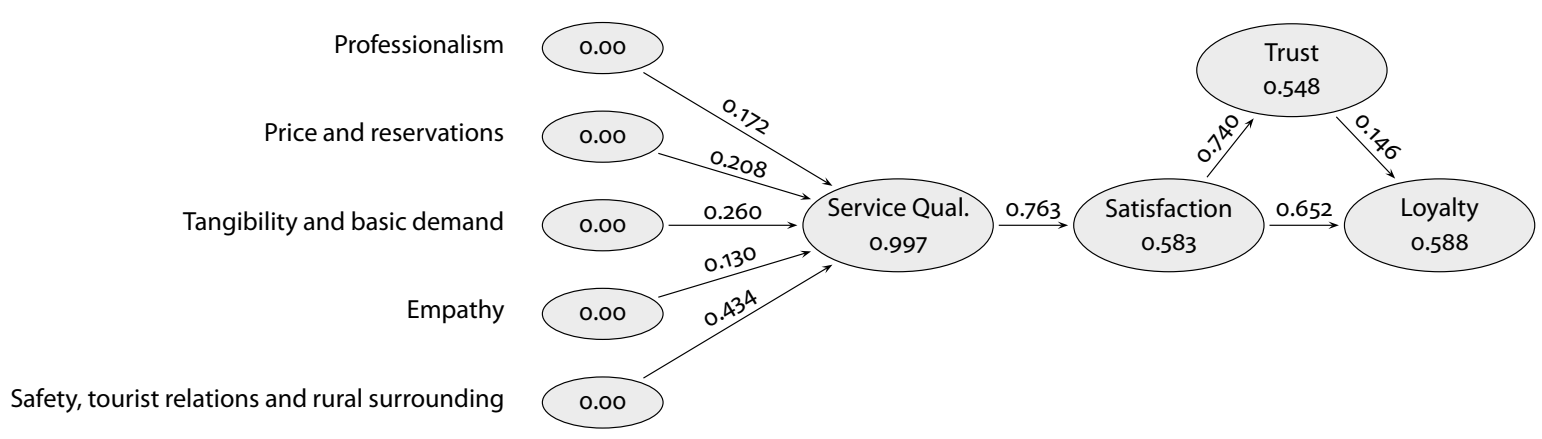

Figure 2 Structural Equation Results

Table 6 Hypothesis Test

\begin{tabular}{llrrrr}
\hline Relation & & $(1)$ & $(2)$ & $(3)$ & $(4)$ \\
\hline Direct & Empathy $\rightarrow$ Service quality & 0.130 & 12.378 & $* * *$ & 0.000 \\
& Professionalism $\rightarrow$ Service quality & 0.172 & 14.187 & $* * *$ & 0.000 \\
& Price and reservationa $\rightarrow$ Service quality & 0.208 & 19.077 & $* * *$ & 0.000 \\
& Safety, tourist relations and rural surrounding $\rightarrow$ Service quality & 0.434 & 20.937 & $* * *$ & 0.000 \\
& Tangibility and basic demand $\rightarrow$ Service quality & 0.260 & 16.010 & $* * *$ & 0.000 \\
& Service quality $\rightarrow$ Satisfaction & 0.763 & 28.914 & $* * *$ & 0.000 \\
& Satisfaction $\rightarrow$ Loyalty (direct relation) & 0.761 & 26.352 & $* * *$ & 0.000 \\
\hline Indirect & Satisfaction $\rightarrow$ Trust & 0.740 & 19.162 & $* * *$ & 0.000 \\
& Trust $\rightarrow$ Loyalty & 0.146 & 2.279 & $* *$ & 0.023 \\
& Satisfaction $\rightarrow$ Loyalty & 0.652 & 12.254 & $* * *$ & 0.000 \\
\hline
\end{tabular}

Notes Column headings are as follows: (1) path coeff., (2) $t$-value, (3) significance level ( $\left.{ }^{* *} p<0.05,{ }^{* * *} p<0.01\right),(4) p$-value.

not sufficiently addressed as most of the rural tourism businesses are small, family-managed rural units often lacking a professional management approach and strategic marketing activities. Better understanding of the key service quality attributes could increase tourist satisfaction and lead to tourist loyalty that manifests as an intention to recommend, to return, and even to pay more.

The results of this study have confirmed that the perceived service quality is formed by 5 dimensions: Professionalism, Price and reservations, Tangibility and basic demand, Empathy, and Safety, tourist relations and rural surrounding. The overall average service quality score is relatively high. Research results indicate that rural tourism managers should pay more attention to the service quality attributes that re- fer to safety measures, including tourists in the local lifestyle, and integration of local activities and events in the tourist offer. Generally, results lead to the conclusions that rural tourism managers and owners paid more attention to the technical service quality elements, but in the future, they need to pay more attention to the soft service quality elements in order to improve overall tourist experience.

Although the mean scores for the Service quality, Satisfaction and Trust are quite high, the mean score for Loyalty as a consequent is lower. This can partly be explained by the motive of novelty where tourists like to visit different tourist destinations rather than to return to the same one. On the other hand, this can serve as useful information to rural tourism managers in rethinking marketing strategies. 
The focus of this study was to examine the relationship between Service quality, Satisfaction and Loyalty and to assess the role of Trust as a mediator. The results of the PLS SEM analysis show that there is a strong significant positive relationship between Service quality and Satisfaction. A similar conclusion has been proven by the study of Loureiro and Kastenholz (2011) and Loureiro and Gonzalez (2008) who applied the RURALQUaL model in Portugal.

Furthermore, it is proven that Satisfaction is an antecedent of Loyalty, although the strength of that relationship is a bit lower than between Service quality and Satisfaction. Due to novelty, not all satisfied tourists tend to return to the same rural tourism unit. The conclusion follows the conceptual background of the relationship Service Quality-Satisfaction-Loyalty. The positive and significant relationship between Service quality, Satisfaction and Loyalty in rural tourism was also confirmed by Loureiro and Gonzalez (2008) and Loureiro and Kastenholz (2011).

The evaluation of the role of Trust as a mediator shows that the mediating role of Trust on the Satisfaction-Loyalty relationship is positive and significant but rather small. Therefore, the hypothesis $\mathrm{H} 3$ is supported. The same results have been proven by the study of Loureiro and Gonzalez (2008), Setó-Pamies (2012), and Lin et al. (2018). The study of Loureiro (2013), conducted on banking services, did not confirm the existence of a relationship between Trust and Loyalty.

In order to understand and meet tourists' expectations and provide a high level of service quality and tourist satisfaction, and finally to increase the rate of loyal tourists, rural tourism managers should periodically use the modified RURALQUAL instrument as a guide for future development actions.

There are some limitations of this study that should be considered in future studies. The main limitation of the research is a relatively small sample size that affects the generalisation of research results. This study included only the actual tourists, but in the following studies it would be useful to evaluate statements of potential tourists. Also, this study was conducted in a geographically limited tourist destination. Future studies could be conducted in different rural tourist regions and in other selective forms of rural tourism. It would be useful to measure service quality solely, in particular rural tourist destinations, in order to obtain more specific results. Since rural tourism is broadly defined and encompasses a wide range of activities, future research should be conducted for specific activities or accommodation types such as diffuse hotels. Also, some other constructs should be considered for inclusion in the model, like, for example, Destination Image or Tourist Experience.

\section{References}

Albacete-Saez, C. A., Fuentes-Fuentes, M. M., \& LlorénsMontes, F. J. (2007). Service quality measurement in rural accommodation. Annals of Tourism Research, 34(1), 45-65.

Ali, F., Rasoolimanesh, S. M., Sarstedt, M., Ringle, C. M., \& Ryu, K. (2018). An assessment of the use of partial least squares structural equation modeling (PLS-SEM) in hospitality research. International Journal of Contemporary Hospitality Management, 3o(1), 514-538.

Almeida-Santana, A., \& Moreno-Gil, S. (2018). Understanding tourism loyalty: Horizontal vs. destination loyalty. Tourism Management, 65, 245-255.

Babakus, E., \& Boller, G. W. (1992). An empirical assessment of the SERVQUAL scale. Journal of Business research, 24(3), 253-268.

Baker, D. A., \& Crompton, J. L. (2000). Quality, satisfaction and behavioural intentions. Annals of Tourism Research, 27(3), 785-804.

Bigne, J. E., Martinez, C., Miquel, M. J., \& Andreu, L. (2003). SERVQUAL reliability and validity in travel agencies. Annals of Tourism Research, 30(1), 258-262.

Chatzigeorgiou, C., \& Simeli, I. (2017). Perception of service quality in agrotourism accommodations: Impact on guest loyalty and re-visit intentions. Journal of Tourism, 3(1), 33-41.

Chen, C. F., \& Tsai, D. (2007). How destination image and evaluative factors affect behavioural intentions? Tourism management, 28(4), 1115-1122.

Cheng, S. (2011). Comparisons of competing models between attitudinal loyalty and behavioral loyalty. International Journal of Business and Social Science, 2(10), 149-166.

Choi, H., Ann, S., Lee, K. W., \& Park, D. B. (2018). Measuring service quality of rural accommodations. Sustainability, $10(2), 443$.

Cronin Jr, J. J., \& Taylor, S. A. (1994). SERvPERF versus SERVQUAL: Reconciling performance-based and per- 
ceptions-minus-expectations measurement of service quality. Journal of marketing, 58(1), 125-131.

Fotiadis, A., \& Vassiliadis, C. (2010). Rural tourism service quality in Greece. E-review of Tourism Research, 8(4), 69-84.

Grgić, I., Hadelan, L., Krznar, S., \& Zrakić, M. (2017). Could rural tourism revitalize rural areas in Croatia? Agroeconomia Croatica, 7(1), 98-108.

Gronroos, C. (1984). A service quality model and its marketing implications. European Journal of Marketing, 18(4), $36-44$.

Hair, J. F., Jr., Hult, G. T. M., Ringle, C., \& Sarstedt, M. (2013). A primer on partial least squares structural equation modeling (PLS-SEM). Sage.

Hair, J. F., Risher, J. J., Sarstedt, M., \& Ringle, C. M. (2019). When to use and how to report the results of PLS-SEM. European Business Review, 31(1), 2-24.

Hair, J. F., Jr., Sarstedt, M., Hopkins, L., \& Kuppelwieser, V. G. (2014). Partial least squares structural equation modeling (PLS-SEM). European Business Review, 26(2), 106121.

Henseler, J., Ringle, C. M., \& Sinkovics, R. R. (2009). The use of partial least squares path modeling in international marketing. In R. Sinkovics \& P. Ghauri (Eds.), New challenges to international marketing (pp. 277-319). Emerald.

Hansen, K. V. (2014). Development of SERVQUAL and DINESERV for measuring meal experiences in eating establishments. Scandinavian Journal of Hospitality and Tourism, 14(2), 116-134.

Hurst, J. L., Niehm, L. S., \& Littrell, M. A. (2009). Retail service dynamics in a rural tourism community. Managing Service Quality: An International Journal, 19(5), 511-540.

Kastenholz, E., Carneiro, M. J., Marques, C. P., \& Loureiro, S. M. C. (2018). The dimensions of rural tourism experience impacts on arousal, memory, and satisfaction. Journal of Travel \& Tourism Marketing, 35(2), 189-201.

Katircioglu, S. T., Mehtap-Smadi, S., Kilinç, C., \& Ünlücan, D. (2012). Service quality and university students' satisfaction on the travel agencies: An empirical investigation from Northern Cyprus. International Journal of Quality and Service Sciences, 4(3), 299-311.

Kim, A. K., \& Brown, G. (2012). Understanding the relationships between perceived travel experiences, overall satisfaction, and destination loyalty. Anatolia, 23(3), 328-347.

Kim-Soon, N., Rahman, A., \& Visvalingam, L. (2014). sE RVQUAL: Can it be used to differentiate guest's perception of service quality of 3 star from a 4 star hotel. International Business Research, 7(7), 37-47.

Ladhari, R. (2009). A review of twenty years of SERVQUAL research. International Journal of Quality and Service Sciences, 1(2), 172-198.

Lewis, B. R., \& Mitchell, V. W. (1990). Defining and measuring the quality of customer service. Marketing Intelligence \& Planning, 8(6), 11-17.

Lin, L., Osman, Z., \& Wang, S. (2018). Indirect effect of trust on customer satisfaction and customer loyalty in Malaysian airline industry. Journal of Economics and Business, 1(2), 134-142.

Loureiro, S. M. C. (2013). The effect of perceived benefits, trust, quality, brand awareness/associations and brand loyalty on internet banking brand equity. International Journal of Electronic Commerce Studies, 4(2), 139-158.

Loureiro, S. M. C., \& González, F. J. M. (2008). The importance of quality, satisfaction, trust, and image in relation to rural tourist loyalty. Journal of Travel \& Tourism Marketing, 25(2), 117-136.

Loureiro, S. M. C., \& Kastenholz, E. (2011). Corporate reputation, satisfaction, delight, and loyalty towards rural lodging units in Portugal. International Journal of Hospitality Management, 30(3), 575-583.

Marković, S., \& Raspor, S. (2010). Measuring perceived service quality using SERVQUAL: A case study of the Croatian hotel industry. Management, 5(3), 195-209.

Marković, S. (2004). Measuring service quality in the Croatian hotel industry: A multivariate statistical analysis. Our Economy, 50(1), 27-35.

Marković, S., \& Raspor Janković, S. (2013). Exploring the relationship between service quality and customer satisfaction in Croatian hotel industry. Tourism and Hospitality Management, 19(2), 149-164.

Marković, S., Raspor, S., \& Šegarić, K. (2010). Does restaurant performance meet customers' expectations? An assessment of restaurant service quality using a modified DINESERV approach. Tourism and Hospitality Management, 16(2), 181-195.

Nam, J. H., \& Lee, T. J. (2011). Foreign travellers' satisfaction with traditional Korean restaurants. International Journal of Hospitality Management, 3o(4), 982-989.

Oh, H., \& Kim, K. (2017). Customer satisfaction, service quality, and customer value: Years 20oo-2015. International Journal of Contemporary Hospitality Management, 29(1), 2-29.

Oliver, R. L. (1999). Whence consumer loyalty? Journal of marketing, 63 (Special issue), 33-44.

Osman, Z., \& Sentosa, I. (2013a). Influence of customer satisfaction on service quality and trust relationship in Malaysian rural tourism. Business and Management Quarterly Review, 4(2), 12-25. 
Osman, Z., \& Sentosa, I. (2013b). Mediating effect of customer satisfaction on service quality and customer loyalty relationship in Malaysian rural tourism. International Journal of Economics Business and Management Studies, 2(1), 25-37.

Ounsri, K., \& Thawesaengskulthai, N. (2019). Hotel service quality factors among different cultures. In 2019 IEEE 6th International Conference on Industrial Engineering and Applications (ICIEA) (pp. 306-312). IEEE.

Parasuraman, A., Zeithaml, V. A., \& Berry, L. (1985). A conceptual model of service quality and its implications for future research. Journal of Marketing, 49(4), 41-50.

Peãa, A. I. P., Jamilena, D. M. F., \& Molina, M. Á. R. (2012). The perceived value of the rural tourism stay and its effect on rural tourist behaviour. Journal of Sustainable Tourism, 20(8), 1045-1065.

Rajaratnam, S. D., Nair, V., Pahlevan Sharif, S., \& Munikrishnan, U. T. (2015). Destination quality and tourists' behavioural intentions: Rural tourist destinations in Malaysia. Worldwide Hospitality and Tourism Themes, $7(5), 463-472$.

Rajesh, R. (2018). Impact of service quality on customer satisfaction of travel agency in Kerala. International Journal of Advances in Scientific Research and Engineering, 4(4), 96-101.

Rozkee, R. M., Jaafar, N., \& Jalal, H. A. (2016). Regression modelling analysis of the relationship between service quality and customer satisfaction: A case of tourist agricultural farm. International Journal of Modelling in Operations Management, 6(1-2), 33-46.

Saneva, D., \& Chortoseva, S. (2018). Service quality in restaurants: Customers' expectation and customers' perception. SAR Journal, 1(2), 47-52.
Setó-Pamies, D. (2012). Customer loyalty to service providers: Examining the role of service quality, customer satisfaction and trust. Total Quality Management \& Business Excellence, 23(11-12), 1257-1271.

Shahin, A., \& Janatyan, N. (2011). Estimation of customer dissatisfaction based on service quality gaps by correlation and regression analysis in a travel agency. International Journal of Business and Management, 6(3), 99-108.

Sirdeshmukh, D., Singh, J., \& Sabol, B. (2002). Consumer trust, value, and loyalty in relational exchanges. Journal of Marketing, 66(1), 15-37.

Su, L., \& Fan, X. (2011, June). A study on the relationships between service quality, satisfaction, trust and loyalty among rural tourism. In Proceedings of the 8th International Conference on Service Systems and Service Management (ICSSSM) (pp. 1-6). IEEE.

Um, S., Chon, K., \& Ro, Y. (2006). Antecedents of revisit intention. Annals of Tourism Research, 33(4), 1141-1158.

Yieh, K., Chiao, Y. C., \& Chiu, Y. K. (2007). Understanding the antecedents to customer loyalty by applying structural equation modeling. Total Quality Management \& Business Excellence, 18(3), 267-284.

Zeithaml, V. A. (200o). Service quality, profitability, and the economic worth of customers: What we know and what we need to learn. Journal of the Academy of Marketing Science, 28(1), 67-85.

Zeithaml, V. A. \& Bitner, M. J. (2003). Services marketing: Integrating customer focus across the firm. McGraw Hill. 